\title{
THE ECHOES OF POLISH ROMANTICISM IN THE NIGGER OF THE "NARCISSUS"
}

\author{
Karol Samsel \\ Warsaw University
}

\begin{abstract}
The aim of the following study is to situate The Nigger of the "Narcissus" in a consistent constellation of Polish-Romantic references, as well as to demonstrate that even though Conrad's plotline evokes reminiscences of his continuous readings of Mickiewicz's epic Pan Tadeusz, his text overcomes Mickiewicz's influence, in Harold Bloom's sense. Numerous references to Juliusz Słowacki and Pedro Calderón de la Barca are evidenced here. Even though, formally speaking, James Wait is constructed in the image of Mickiewicz's Jacek Soplica from Pan Tadeusz, these seeming influences are deceptive. The stylization of Calderón's Don Fernando from The Constant Prince (which Juliusz Słowacki translated into Polish), and the martyr and Carmelite prophet, Marek Jandołowicz, from Słowacki's play Father Marek [Ksiadz Marek], turn out to be more decisive and more deeply grounded influences on the Wait character.
\end{abstract}

Keywords: Joseph Conrad, The Nigger of the "Narcissus, " Polish Romanticism, Adam Mickiewicz, Juliusz Słowacki, genesis philosophy, Pedro Calderón de la Barca

In the letter to Kazimierz Waliszewski that Conrad wrote on the $5^{\text {th }}$ of December 1903, from Pent Farm, about The Nigger of the "Narcissus", he states:

I consider myself to be the last seaman of a sailing vessel. Anyway, no one will be writing any more about that old sea life. As a work of fiction, The Nigger puts an ultimate seal on that epoch that at the same time marks the end of the sailing fleet. I feel that deeply each time I look at the English Channel where nothing but smokestacks are to be seen nowadays. ${ }^{2}$

The recipient of Conrad's letter, a Polish historian living in France, could perfectly infer from the writer's confession clear allusions to Mickiewicz's Pan Tadeusz, including its epilogue. In light of the above comparison, Conrad in his introduction to The Nigger of the "Narcissus" would echo and reevaluate the gesture of Mickiewicz's

${ }^{1}$ The author would like to acknowledge that the methodology of the present article was inspired by a research project entitled "Conrad \& Spectralities" carried out by Dr. hab. Agnieszka AdamowiczPośpiech and Dr. hab. Jacek Mydla at the Institute of English Cultures and Literatures of the University of Silesia in Katowice.

2 J. Conrad, "To Kazimierz Waliszewski, Pent Farm, $5^{\text {th }}$ December, 1903” [in:] The Selected Letters of Joseph Conrad, ed. L. Davies, Cambridge: Cambridge UP, 2015, p. 172. 
epilogue to Pan Tadeusz. "The last seaman of a sailing vessel" is a characterization of essentially the same rank as "The Last Bailiff of the Tribunal"' in Pan Tadeusz, or, to expand: These are, perhaps, the last looks that they'll get at, their final chance to view, this dignified Polish dance [called "polonaise" - K. S.], led in such a way that they won't forget. ${ }^{4} 1812$ was a twilight year for Lithuania and it served Conrad in his novella as a crucial and organic point of reference. One could risk in this case plenty of theses about the intertextuality of Conrad's novella. One could, for example, assert the thesis that Conrad's sailing vessel stands for Soplica's "theatre on the water," to use Mickiewicz's language; and the West Indian black sailor James Wait, dying on board the Narcissus, is a transcultural variation of Jacek Soplica, Mickiewicz's character whose literary mythology must have fascinated Conrad as he based many of his characters created in the years 1896-1900 on this prototype (starting with Karain and ending with Jim).

One could carry it further and claim that in the space marked parabolically by Pan Tadeusz, the crew of the "Narcissus" turns out to be Soplicowo-like. Mean Donkin resembles Gerwazy, and the aesthetic style of the novella does not spring from nowhere, but is mediated constantly through the innovative aesthetics of Pan Tadeusz. The case of Pan Tadeusz is instructive: even the influences suggested by Conrad can be illusory and we need to take them into account with certain skepticism. The author of Lord Jim constructs his own Polish-Romantic intertextuality - and this occurs in a few significant cases - as well as frequently narrowing them down to the entirely synthetic dimension of the repertoire of already existing contexts, which does not facilitate viewing Conrad as "the author of great wholes." Conrad certainly favors Pan Tadeusz and he wants to be identified as a reader of Pan Tadeusz, especially by Poles. Let's add here: not just a "reader," we mean here a reader-writer who considers Mickiewicz's masterpiece the material of inspiration. In his book, Conrad and His Contemporaries, Józef Hieronim Retinger digresses to focus on Conrad's style and recollects this directly experienced scene:

In parenthesis I would like to add that there is one feature in Conrad's art that is unique in English literature. Writers in this country when depicting Nature, the landscape and its phenomena, usually portray them in a static manner and seize the passing moments as if they were frozen in immobility. They give successive pictures as if a cinematographic ribbon were cut into separate stills. Wordsworth is a typical example of an author who, when describing events in Nature, renders them in successive immobile landscape paintings. Conrad, on the other hand, puts movement into his words, and catches Nature in the act of changing from one mood into another. When I commented on that to him and observed that this is a typically Polish verbal procedure, he made no reply for a moment, then handed me a faded volume out of his library, saying: "Here is the reason." The book was Pan Tadeusz. ${ }^{5}$

${ }^{3}$ A. Mickiewicz, Pan Tadeusz or The Last Foray in Lithuania: A History of the Nobility in the Years 1811 and 1812, transl. from Polish by L. Kress, HarrowGate Press 2006, p. 6, http://leonardkress.com/ Pan\%20Tadeusz.pdf [access: 19.07.2018].

${ }^{4}$ Ibid., p. 256.

${ }^{5}$ I quote here after English edition of J. H. Retinger, Conrad and His Contemporaries: Souvenirs, New York: Roy Publishers, 1943, pp. 112-113. 
For Julian Przyboś, Mickiewicz's epic poem about the last foray in Lithuania is a masterpiece of great, beyond natural, homeostasis. It's a poem of golden times, the result of colliding dynamics and harmonious opposites. ${ }^{6}$ Maria Dąbrowska had an identical observation in reference to The Nigger of the "Narcissus." In her essays on Conrad, in Mickiewicz fashion, she calls the book "the grand epic of the "Narcissus": "quiet departure from harbor, the rising of the storm, and the intensification of the violent play of emotions that affect the crew — until Jim's death — and then the fading away and the pacification of the theme just as the crew disperses through the streets of an English harbor town. This sounds like a perfect symphony."”

Johannes Volkelt, a German theoretician of empathy, expressed a similar thought about Mickiewicz's grand epic at the turn from the $19^{\text {th }}$ to the $20^{\text {th }}$ century. He wrote about an unparalleled, unique miracle of reception: "When we read Pan Tadeusz, we feel a wide and deep stream of joie de vivre flow through our heart such that truly symphonic optimism penetrates us." Conrad also might have experienced this linguistically kaleidoscopic "miracle of reception," which could have evoked in him the atavistically creative instinct of the Bloomian anxiety of influence.

If we acknowledge that, regardless of the esteem Conrad had for Pan Tadeusz, the writer's fear of the influence of this grand epic existed, we could find in the text of the novel evidence of Bloom's six revisionary ratios - the techniques of overcoming the anxiety of influence: clinamen, tessera, kenosis, daemonization, askesis, and-finally-apophrades. ${ }^{9}$

The "Narcissus" equals Soplicowo on water, we could say, generalizing. Conrad's clinamen constitutes a revision of this starting point. The "Narcissus" is the whole province of Soplicowo, ${ }^{10}$ which is to say not only Soplicowo from the first five books of Pan Tadeusz, but also Dobrzyń on the water from the remaining part of Pan Tadeusz. ${ }^{11}$ The crew of the "Narcissus" acquires the roles of the Soplicowo richer nobility and the poorer nobility from the Dobrzyń settlement (the so called "zagrodowa szlachta" ${ }^{\prime 2}$ ). We notice the parallel especially during the scene of the rebel-

${ }^{6}$ J. Przyboś, "Widzę i opisuję" [in:] idem, Czytając Mickiewicza, Warszawa: Oficyna Wydawnicza Rytm, 1998, p. 99.

${ }^{7}$ M. Dąbrowska, "Fantazja Almayera, Murzyn z załogi "Narcyza””' [in:] eadem, Szkice o Conradzie, ed. with introduction, and footnotes E. Korzeniewska, Warszawa: Czytelnik, 1974, p. 50.

${ }^{8}$ I quote after Julian Krzyżanowski. J. Krzyżanowski, "Wielkość i oryginalność Pana Tadeusza," Pamiętnik Literacki 1948, no. 38, p. 263.

${ }^{9} \mathrm{~K}$. Gajewski, “Lęk przed wptywem. Teoria poezji, Harold Bloom, trans. Agata Bielik-Robson, Marcin Szuster," Pamiętnik Literacki 2006, no. 3, pp. 251-252.

10 "Oh, Soplica manor, if your white walls / still shine within lindens that grow sky high, / If nobles still gather inside your halls / to enjoy the Judge's hospitality, / to Bucket's health they would certainly toast -- / without his deeds, and his vitality, / the manor'd be destroyed, the Judge a ghost." A. Mickiewicz, Pan Tadeusz, op. cit., pp. 182-183.

11 "The Dobrzyn settlement was widely known / in Lithuania for male courage / And female beauty; it had formerly grown to a mighty and populous assemblage", "The Dobrzynskis differed from their countrymen. / Besides speaking in their own dialect, / they seemed to be pure-blooded Mazovian: black hair, blue eyes, broad foreheads held erect, and aquiline noses." Ibid., pp. 127, 128.

12 "The sum of the Soplicas' strengths so various", "A soldier's spirit and good looks." Ibid., s. 21. 
lion on board the "Narcissus," which would be the equivalent of Mickiewicz's foray. Just before the sailors' strike, James Wait is terrorized by Podmore, the cook. This moment of confusion is used by Donkin (an equivalent of Mickiewicz's Gerwazy) to incite the crew against the ship's command.

\begin{tabular}{|c|c|}
\hline J. Conrad, The Nigger of the "Narcissus" & A. Mickiewicz, Pan Tadeusz \\
\hline $\begin{array}{l}\text { Captain Allistoun shook a forefinger at the } \\
\text { angry bronzed face of the speaker. "You - } \\
\text { you hold your tongue" - he said, warningly. } \\
\text { - "This isn't the way", clamoured two or three } \\
\text { younger men. - Are we bloomin' masheens?" } \\
\text { inquired Donkin in a piercing tone, and } \\
\text { dived under the elbows of the front rank. - } \\
\text { "Soon show "im we ain't boys..." - "That's } \\
\text { the bloomin' ticket". Captain Allistoun said } \\
\text { sharply to the second mate: "Keep quiet, Mr. } \\
\text { Creighton" and stood composed in the tumult, } \\
\text { listening with profound attention to mixed } \\
\text { growls and screeches, to every exclamation } \\
\text { and every curse of the sudden outbreak. }{ }^{13}\end{array}$ & $\begin{array}{l}\text { In the center, Maciek was mute; / of all the } \\
\text { heads, his was motionless. / The Baptist } \\
\text { was attempting to refute / the latest motion, } \\
\text { seeming to caress / his club - his head resting } \\
\text { upon the knob, / looking like a pumpkin on } \\
\text { a pole. / Swaying from side to side, he told the } \\
\text { mob: / "Baptize!" The Razor then resumed his } \\
\text { role / of shuttlecock, crazily rushing about / } \\
\text { from Maciek's bench, to where the Baptist sat. } \\
\text { / The Bucket paced across the room to shout } \\
\text { / at dissenting nobles, to tell them that/they } \\
\text { must agree with all the Dobrzynskis. / One } \\
\text { yelled, "To shave", another, "To drench", / As } \\
\text { the level of furor did increase / Maciek's jaw } \\
\text { clearly began to clench. }{ }^{14}\end{array}$ \\
\hline
\end{tabular}

The example of Conrad's reminiscence of foray, cited in the above table, could be read in the spirit of Bloom's kenosis, as well as "daemonization." As Krzysztof Gajewski explains in the case of kenosis, "the aim of this technique is extremely deceitful: a poet - ephebe prostrates himself, and cutting himself off from any inspiration and poetry, surrenders his poetic weapons only so his predecessors, in whose shadow he creates, become diminished as the result of this treacherous act. ${ }^{15}$

In that mode, the whole situation taking place in Dobrzyński's backwater is duplicated in a one-to-one ratio in Conrad's novel. The cacophonous screams of the "Narcissus" crew are likened to the screams of Konewka [The Bucket], Kropiciel [The Baptist], and Brzytewka [The Razor]. The parallelism of reactions is accompanied by the parallelism of the figures: captain Allistoun, just like Maciek, remains unmoved - in Conrad amidst the ballyhoo and in Mickiewicz amidst the screaming crowd.

${ }^{13} \mathrm{~J}$. Conrad, The Nigger of the "Narcissus": An Authoritative Text, Backgrounds and Sources Reviews and Criticism, ed. R. Kimbrough, New York: Norton, 1979, p. 74.

${ }^{14}$ A. Mickiewicz, Pan Tadeusz, op. cit., p. 140. "Maciek stary w pośrodku jeden siedział niemy / I jedna głowa jego była nieruchoma. / Przeciw niemu stał Chrzciciel, zwieszony rękoma / Na maczudze, a głową na końcu maczugi / Wspartą kręcił jak tykwą wbitą na kij długi / I na przemiany to w tył, to się w naprzód kiwał. / I ustawicznie: 'Kropić, kropić' wykrzykiwał. / Wzdłuż izby zaś przebiegał Brzytewka ruchawy / Ciągle od Kropiciela do Macieja ławy. / Konewka zaś powoli wszerz izbę przechodził / Od Dobrzyńskich do szlachty, niby to ich godził: / Jeden wciąż wołał 'Golić' - a drugi 'Zalewać!' / Maciek milczał, lecz widno, że się zaczął gniewać.” A. Mickiewicz, Pan Tadeusz, ed. J. Krzyżanowski, vol. IV, Warszawa: Państwowy Instytut Wydawniczy, 1955, p. 199.

${ }^{15}$ K. Gajewski, op. cit., p. 252. 
Within the tesserae procedure "the ephebe has to complete and complement the precursor, as if he were the missing part of the whole. At the same time he ascribes new meaning to the outcome, different from the one the precursor intended, which qualifies it as an antithetical stage." ${ }^{16}$ In The Nigger of the "Narcissus," what is antithetical manifests itself in Conrad's attitude to the finale of the tenth book of Pan Tadeusz, that is to say to Jacek Soplica, wounded in battle, confessing to Gerwazy, and Jacek's death. James Wait dies in the presence of Donkin. However, unlike Mickiewicz's Gerwazy, Donkin - unable to control his anger-interrupts Wait's confession and hastens his death.

The dying Wait-is depicted indirectly, via a dynamic projection of light that brings to mind Conrad's inspiration by the impressionistic avant la lettre, the scene of Konrad Wallenrod's death. These are important coincidences. Possibly such conclusions subtly suggesting that Conrad in The Nigger of the "Narcissus" was imitating the descriptive techniques, employing light, present in Pan Tadeusz and Konrad Wallenrod would also verify current scholarship about Conrad's narrative impressionism and unexpectedly enrich it with the possibility of Mickiewicz's legitimization:

\begin{tabular}{|c|c|}
\hline J. Conrad, The Nigger of the "Narcissus" & A. Mickiewicz, Konrad Wallenrod \\
\hline $\begin{array}{l}\text { He [Donkin - K. S.] spun round as though he } \\
\text { had been tapped on the shoulder. He was just } \\
\text { in time to see Wait's eyes blaze up and go out } \\
\text { at once, like two lamps overturned together } \\
\text { by a sweeping blow. Something resembling } \\
\text { a scarlet thread hung down his chin out of } \\
\text { the corner of his lips-and he had ceased to } \\
\text { breathe. }{ }^{17}\end{array}$ & $\begin{array}{l}\text { He spoke, looked on the window, and he fell } \\
\text { / But ere he fell, he cast the lamp to earth. / It } \\
\text { three times glimmered with a circling blaze, / } \\
\text { That rested latterly on Konrad's brow; / And in } \\
\text { its scattered flow the fire's rust gleamed, / But } \\
\text { ever deeper into darkness sank. / At length, } \\
\text { as though it gave the sign of death, / One last } \\
\text { great ring of light shot forth its blaze; / And in } \\
\text { this blaze were seen the eyes of Alf, / All white } \\
\text { in death, and now the light was dark. }\end{array}$ \\
\hline
\end{tabular}

One has to admit that Conrad seems to select here very skillfully one of the most ingenious fragments of Mickiewicz poetic prose. In one rotational scene the narrator has the reader trace: 1 . tossing up the lamp in the air, 2. thrice turning the vessel, causing three parallel movements of light, 3 . the landing of the vessel and its perfectly situated resting place establishing the last spot of light: the face of the dying Lithuanian, 4. performance within performance, such as the theater of Wallenrod's agony, taking place in time, lasting until the core of the fire lasts, which means a few or a dozen minutes, 5 . a rapprochement of eyes, and, then the play based on them, via the antagonism of light and color: as the chiaroscuro recedes we observe how the corpse's eyeball whitens.

${ }^{16}$ K. Gajewski, op. cit., pp. 251-252.

${ }^{17}$ J. Conrad, The Nigger of the "Narcissus"..., op. cit., p. 95.

${ }^{18}$ A. Mickiewicz, Konrad Wallenrod: A Historical Poem, transl. from the Polish into English Verse by Miss M. Ashurst Biggs, London: Trübner \& Co., 1982. 
In The Nigger of the "Narcissus," comparing James Wait's eyes to two overturned lamps seems to be a clear reference to Konrad Wallenrod, and at the same time a subtle revocation of the influence of the tenth book of Pan Tadeusz, as the agony of Jacek Soplica becomes replaced with the agony of Konrad Wallenrod. Thus, antithetical tessera evidently transitions into less radical clinamen.

The additional value of such a constructed allusion is the preservation of the rich polyvalence of the precursor's text. In Konrad Wallenrod we notice that: the lamp "perfectly" turns three times in the air, and, after its luminous acrobatics (as if it were a living creature, trained or gifted with artistic intuition) also "perfectly" lands in the vicinity of corpse's face. Conrad adopts this perfectness of matter as a result of the influence of his precursor, Mickiewicz's poetic prose. In these specific confines the concept of Romantic meta-theatricality was born and the perfect acting of nonanimate objects forming clusters of views, particularly landscapes, constitutes a modern craft of Mickiewicz, apparent not only in Pan Tadeusz, but also in Crimean Sonnets [Sonety krymskie], whose echoes we will find in Conrad's The Lagoon and the first chapter of Nostromo.

In this case only, I have to disagree hook, line, and sinker with Cedric Watts's comment that the scene with lamps of Wait's dying eyes was modeled on the scene of Forestier's agony, observed by Duroy, in Bel Ami. Intertext independently indicates in this case both Guy de Maupassant as well as the poetic prose of Mickiewicz. In both of these cases, the sphere of influence cannot be determined unequivocally. ${ }^{19}$

Looking from another side, and exposing the intertextuality of The "Nigger of the "Narcissus" - not with Mickiewicz but with Słowacki's works, we should emphasize the congruity of the descriptions of James Wait's and Don Fernando's agony (the latter is from Słowacki's The Constant Prince, which is the Polish poet's paraphrase of one of the most important plays by Pedro Calderón de la Barca). This similarity is symptomatic, as it effaces a consistently paradigmatic similarity between Wait and Soplica, whose agony significantly differs from Wait's death. Mickiewicz's schema dominates only in the general sphere of references in the description of Wait's final hours, at the same time the confrontation of Donkin and Waits resembles the confrontation of Gerwazy and Soplica.

Calderón, the author of the primary play that Słowacki translated in 1844 (and that translation became a way of appropriating the text), remained for Conrad a living point of reference. It is highly probable that Conrad encountered The Constant Prince via Słowacki's variation in the spirit of genesis philosophy. John G. Peters refers to existing and significant, albeit small, scholarship dedicated to the parallels between Conrad and Calderón. The complex of Calderón's "constant princes" constitutes Jim's complex in Conrad, as well as later Conrad's protagonists, who are obverses and reverses of Jim: starting with Nostromo and ending with Razumow. As Peters writes in Joseph Conrad's Critical Reception, the fundamental research on Calderonism was Camille R. La Bossiere's Conrad and the Science of Unknowing:

${ }^{19}$ C. Watts, "Commentary" [in:] J. Conrad, The Nigger of the 'Narcissus', ed., with an introduction and notes, by C. Watts, London: Penguin Books, 1989, p. 141. 
Unlike other studies of Conrad's sources, Camille R. La Bossière's Joseph Conrad and the Science of Unknowing (1979) suggests that Calderón is an important and generally unacknowledged source. La Bossière argues that Calderón influenced a vast number of Conrad's acknowledged sources and that Conrad himself regarded Calderón highly. Consequently, he sees an Eastern or dream logic providing a key to much of Conrad's writing; since Conrad could not employ traditional logic to understand the enigma of human existence, he employed dream logic instead (as evidenced by its frequency and prominence). ${ }^{20}$

The agony that ate up the body of the black sailor and made him into a ghost, as well as into a blurred creature with "unclear ontological status," 21 seems to be a transparent reminiscence of the images of dying and starvation of the Portuguese infant prince, Don Fernando, while under the Moor's captivity. In his play The Constant Prince [Ksiaże Niezłomny] Słowacki turned him into the medium of genesis philosophy; into so-called terrestrial spirit ("Duch globowy" is Słowacki's term for the terrestrial angel) that offers itself as a sacrifice in the historic and cosmic process of world development. James Wait manifests many features of this form of the prototype for the genesis-philosophy hero. It would be worth outlining the basic elements of Słowacki's genesis philosophy, whose proclamation became the main task of his late-life literary work.

In the continual cycle of the genesis of metempsychosis, Golgotha became the new Bethlehem, decay - a new birth; death — the birth of a new reality; the bodybloody ransom for passing onto the new reality and, more than that - priceless price that could tip the scale of cosmic battle; the price not only in individual salvation but also group salvation, the elevation of all existing and feeling spirits. This process of rising and elevating, so called "tier-ing" [szczeblowanie], with its transformations and nuances has become a fulcrum of all the genesis plays of the poet, starting with Father Marek [Ksiadz Marek] and The Silver Dream of Salomea [Sen srebrny Salomei], and finally The Constant Prince. Conrad could have come across them in numerous places, in the popularized Brockhaus's edition that came out in the 1860s, and also in the famous three-volume edition of Stowacki's Posthumous Works prepared by Antoni Małecki in 1866.

These elements seem to emanate from a reading of The Nigger..., if even Douglas Brown in his critical commentary on Conrad's novel notices in particular motifs the contexts which, seen from the perspective of various Słowacki mystical work, can be freely characterized as genesis-like. Here is his commentary on James Wait's rescue from death in the storm, more precisely, the digging of him out of the submerged cabin.

We worked fiercely: the description of the rescue of the Negro has an under-current of imagery running through, likening the whole process to the delivery of a newborn child from the womb. This is worth thinking about, in regard to the episode's place in the story. The other current

${ }^{20}$ J. G. Peters, "Development of Modern Conrad Commentary" [in:] idem, Joseph Conrad's Critical Reception, Cambridge: Cambridge UP, 2013, p. 145.

${ }^{21}$ Z. Stefanowska, "Próba zdrowego rozumu" [in:] eadem, Próba zdrowego rozumu. Studia o Mickiewiczu, Warszawa: Państwowy Instytut Wydawniczy, 1976, pp. 34-35. 
of images and allusions, that suggests how Wait is being freed from premature internment in a coffin, you will probably have detected already. ${ }^{22}$

What Brown notices here is a metaphor of a grave which is a cradle, and the genesis-like figure of the end that becomes the beginning, extrapolated here onto the events taking place on board the "Narcissus." In Father Marek, the Golgotha of the old Poland is transformed into the Bethlehem of new Poland through the power of mystical metamorphosis. The quotes from the play, specifically from Father Marek's monologue, serve as evidence here: "Ja ksiądz prosty, powiem tobie, / Że tu leży Polska w żłobie, / Lecz Polska nie tego wieku, / Żywa - nie przez nasze czyny. Szanuj sen świętej dzieciny, / Która, gdy oczy otworzy / A uczuje boleść ciała, / Najpierwej będzie płakała, / Taka ją ciemność zatrwoży / Z naszych grobów uczyniona, / I brak matczynego łona / Tak ją w żłobeczku rozkwili”. At the same time Jandołowicz declares: "Nie wezmę piastować żłobu - / Bom jest już podobny snowi, / Bliski męczeńskiego grobu." ${ }^{23}$ Similarly, dying in Moorish captivity, Don Fernando becomes a thorn in his friends' and enemies' side. He is in equal degree a mystical living corpse and a spiritual pang of conscience. As Mulej, complaining to the king of the Moors and commiserating with the captive, declares: "Z członków się jego nikczemnych / Zrobił trup, a z oczów jamy...". And he adds "Bo... (ach, głos mi w piersiach głuchnie) / Bo ten książę trupem cuchnie, / Gnije żyw, z kości opada; / Nikt z nim nie żyje, nie gada, / Nikt przy jego mazamorze, / Od swądu wytrwać nie może; / Tak kość, ciało, co się cegli, / Trąci i tak się rozpada, / Że go już wszyscy odbiegli."”24

Undoubtedly, the arduous as well as constantly doubted agony of Wait in The Nigger of the "Narcissus" makes him into a ghost, at first glance - perhaps-a remote equivalent of Gustav from the Fourth part of Mickiewicz's Dziady. Essentially, however, the context becomes unclear - what are Polish Romantic figures Wait could draw upon? What Mickiewicz figures could these be? Jacek Soplica, Konrad Walenrod, Gustav? All of them at once? The multi-faceted context of Słowacki's genesis texts serves to aid in this query of the Polish intertextuality of Conrad. As it seems, in The Nigger of the "Narcissus" we come into contact with the melting of plots and contexts, and a hybrid amalgam of motifs from Pan Tadeusz and The Constant Prince. One should not forget about Father Marek-a prototype of Słowacki's titular protagonist was a Carmelite monk, Marek Jandołowicz, a chaplain

${ }^{22}$ D. Brown, "Notes" [in:] J. Conrad, The Nigger of the 'Narcissus', ed. with a critical commentary by D. Brown, London: University of London Press Ltd., 1960, p. 180.

23 "I am a simple priest, I tell you / And here lies Poland in a crib, / But not Poland of this age / Alive not through our deeds, / Respect the dream of the Holy child, / Who, when it opens its eyes / And feels the pain of the body / Will cry first / As the dark from our tombs woken / Will frighten it /And the want of mother's womb / Will make it chirp in the crib", "I cannot manage the crib, / Cause I'm more like a dream, / Approaching the martyr's tomb.” J. Słowacki, "Ksiądz Marek” [in:] idem, Dzieła wybrane, selection and introduction M. Bizan and P. Hertz, Warszawa: Ossolineum, 2009, vol. II, pp. 19-20.

24 "From his wicked limbs / the corpse formed, from his eyes - pits...". "Cause... (oh, my voice deafens in my breast!) / this prince reeks of death, / rotten alive, his bones fall off; / No one lives and speaks with him, / No one at his Moorish cell / can't resist the stench; / That's how the bone, the body - as a brick, / stinks and crumbles down, / all abandoned him". J. Słowacki, Ksiażę Niezłomny. (Z Caledrona de la Barca). Tragedia we trzech częściach [in:] idem, Dzieła wybrane, op. cit., vol. II, pp. 265-266. 
of the Bar Confederation whose first monastic location was Berdyczów, where Konrad Korzeniowski was born, and which also served as confederation spot, just like Bar.

James Wait, is just like Jandołowicz, and just like Słowacki’s Don Fernando:

He was absurd to the point of inspiration. He was unique, and as fascinating as only something inhuman could be; he seemed to shout his denials already from beyond the awful border. He was becoming immaterial like an apparition; his cheekbones rose, the forehead slanted more; the face was all hollows, patches of shade; and the fleshless head resembled a disinterred black skull, fitted with two restless globes of silver in the sockets of eyes. ${ }^{25}$

Similarly to how the crew of "Narcissus" are terrified by Wait, so are the members of the Moorish court terrified, if not terrorized, by the sight of the dying Don Fernando. Feniksana curses him: "Puść mnie, oddech mnie twój parzy, / Głos zabija, szaty cuchną. / Puść mnie ty, człowiecze próchno! / Szaty mi rękami skazisz." ${ }^{26}$ Don Henryk, on the other hand, confesses to a feeling of horror: "Bracie, opuszcza mnie męstwo, / Zda się, że czaszkę dwujamną / Miał ten..."27

Wait becomes stylized as Don Fernando particularly in the fifth chapter of the novella; in the long, rising sequence of accruing images of decay. Just as Fernando is perceived by Mulej, Feniksan, and the King, so is Wait perceived by his supporters, as well as staunch enemies. Donkin "saw him long, lean, dried up, as though all his flesh had shriveled on his bones in the heat of a white furnace; the meagre fingers of one hand moved lightly upon the edge of the bunk playing an endless tune."28

James Wait, similarly to Don Fernando (and also to priest Marek Jandołowicz), with his spiritual aura changes the moral aura of his surroundings:

He influenced the moral tone of our world as though he had it in his power to distribute honours, treasures, or pain; and he could give us nothing but his contempt. It was immense; it seemed to grow gradually larger, as his body day by day shrank a little more, while we looked. It was the only thing about him — of him — that gave the impression of durability and vigour. It lived within him with an unquenchable life. It spoke through the eternal pout of his black lips; it looked at us through the impertinent mournfulness of his languid and enormous stare. We watched him intently. He seemed unwilling to move, as if distrustful of his own solidity. The slightest gesture must have disclosed to him (it could not surely be otherwise) his bodily weakness, and caused a pang of mental suffering. He was chary of movements. He lay stretched out, chin on blanket, in a kind of sly, cautious immobility. Only his eyes roamed over faces: his eyes disdainful, penetrating and sad. ${ }^{29}$

Wait's funeral in the sea can certainly claim many inspirations, but it also reaches its equivalence in the image of Don Fernando's funeral and Słowacki's genesis mysticism. A bier containing a shroud with Wait's dead body, laid out on wooden planks

${ }^{25}$ J. Conrad, The Nigger of the "Narcissus"..., op. cit., p. 85.

26 "Let me go, your breath scalds me, / your voice kills, your clothes stink, let me go you, rot! / your hands would infect my robes”. J. Słowacki, Książę Niezłomny..., op. cit., p. 284.

27 "Brother, my valor leaves me / It seems that he had / a skull with both cavities." Ibid., p. 287.

${ }^{28}$ J. Conrad, The Nigger of the "Narcissus"..., op. cit., p. 172.

${ }^{29}$ Ibid., p. 86. 
could be paralleled to the coffin with the Portugese infant lowered down the walls into the hands of the despairing father, prince, and brother. What is striking and symptomatic about Wait's funeral at sea is the imagery of Pentecost and the symbolism if its liturgical ritual in the Polish Catholic Church, known as, "zielone świątki" [green holiday]. Even though the feast is not referenced directly, its characteristic symbols emerge. Firstly, during the ceremony: "the red ensign, at half-mast, darted out and collapsed again on the grey sky, like a tongue of flickering fire" ${ }^{\prime 30}$ and this would suggest tongues of fire and the Descent of the Holy Spirit from the Acts of the Apostles. Secondly, after the corpse is deposited in the sea, a "fair wind" picks up: "Fair wind - fair wind' muttered the men going to the braces. It came with the sound of a lofty and powerful sigh." ${ }^{31}$

It is quite difficult not to think about Father Marek, the play whose second act takes place fully during the Pentecost in 1768. The feast celebrated in Bar becomes a symbol of overturning the spirit and the peak of the national metempsychosis. As the Carmelite monk in the prophetic rupture explains: "Więc i te drzewa żałobne, / W Zielone Świątki sadzone, / [...] Te drzewa, to harfy boże, / [...] Od aniołów niewidzialnych / Duchową ręką trącane." ${ }^{32}$ Then, in conversation with Starost's son, we hear the following declaration from the priest:

KSIĄDZ MAREK:

Przed wieczorem

$\mathrm{Z}$ harmat będę miał słuchaczy,

Bo z całą szlachtą, z nieszporem,

Wiodąc nawet tłum żebraczy,

Pójdę na wroga.

STAROŚCIC:

Dziś, panie?

KSIĄDZ MAREK:

Dzisiaj, w dzień Zielonych Świątek. ${ }^{33}$

Słowacki's genesis system, which is not in the form of bodily religion, distinguishes body as non-returnable and insolvent, a sort of "blood currency" which, if used well, can contribute to "tier-ing" from live beings to higher spiritual ones. It is hard to determine whether Conrad read Słowacki's genesis works, and, even harder to determine what he was able to get out of it. Conrad, however, seems to be familiar with Słowacki types. One can neither confirm nor exclude that Conrad adopted, in a sense, the basic laws of this genesis theory of the body. In Conrad, the rotting-whilealive Wait's body becomes distinguished as the only thing about him —of him — that

${ }^{30}$ Ibid., p. 98.

${ }^{31}$ Ibid., p. 99.

32 "Then also these mournful trees / planted on the Pentecost, [...] / These trees - are God's harps, [...] / Dabbed by the mystical hand / Of the invisible angels". J. Słowacki, Ksiadz Marek, op. cit., p. 63.

33 "FATHER MAREK: I would have my listeners / among the cannons / before the evening, / cause I'll move on the enemy / with all the gentry, all the vespers' folks / leading even the crowd of beggars. STAROST'S SON: Today, Father? FATHER MARK: Today, on the day of Pentecost". Ibid., p. 42. 
gave the impression of durability and vigour. ${ }^{34}$ Unscattered, "compressed" remains, as if they possessed a will, one, consistent, and separate from subject, as well as separate identity — constitute coincidentia oppositorum, characteristic of Słowacki's genesis works, especially The Constant Prince.

Although the timing was close, Conrad did not encounter a theatrical adaptation of The Constant Prince in Kraków. His departure for Marseille on October 13, 1873 happened to be four days before the Cracovian preview of the play that took place at Juliusz Słowacki City Theatre. ${ }^{35}$ In these years (1877-1914) eight adaptations of the play took place, four of which took place before Conrad visited Kazimierówka in 1890. The author of Lord Jim might have come across the 1859 Warsaw edition of The Constant Prince or the Nauburski edition from 1861. More surely, however, Conrad held in his hand one of the four popular Leipzig editions $(1861,1862,1868$, or 1876). Through 1891 Słowacki's congenial translation of Calderón had thirteen editions; five of which came out in Lviv, two in Kraków, and two in Tarnów. ${ }^{36}$

Despite the fact that, undoubtedly, Jacek Soplica from Pan Tadeusz is the analogue of James Wait, the black sailor's death is diametrically opposed to Soplica's blissful death, which - according to Iwona Drobczuk-Zwolińska - at first "full of painful seriousness, and lacking the sign of terror" later "acquires the mild form of transition from material being into a spiritual one." ${ }^{37}$ Słowacki's context is quite a different case, together with the intertext of The Constant Prince, which eclipses the rudimentary intertext of Pan Tadeusz. It is in the former where the source of thanatocentrism in The Nigger of the "Narcissus" derives. However, the thanatocentrism is also drawn from Father Marek. Treugutt characterized Father Marek's creation in Słowacki acutely as the creation "of an indomitable prince on the ruins of Bar." 38

Perhaps the most distinctive manifestation of mystical "funeralism" in Słowacki's play occurs during Father Marek's vision in which he accompanies the newly born Christ in Bar as he dreams for the first time on earth. The Carmelite monk warns: „Szanuj sen świętej dzieciny, / Która, gdy oczy otworzy [...] / A uczuje boleść ciała, / Najpierwej będzie płakała, / Taka ją ciemność zatrwoży / Z naszych grobów uczyniona / I brak matczynego łona / Tak ją w żłóbeczku rozkwili" "39. Here we are reminded of natal-funeral imagery in The Nigger of the "Narcissus," commented on by

${ }^{34}$ J. Conrad, The Nigger of the "Narcissus"..., op. cit., p. 19.

${ }^{35}$ Bibliografia literatury polskiej "Nowy Korbut" - vol. 11: H. Gacowa, Juliusz Stowacki, Wrocław 2000, p. 77.

${ }^{36}$ Ibid.

${ }^{37}$ I. Drobczuk-Zwolińska, "Dwie śmierci romantyczne (Jacek Soplica z Pana Tadeusza Adama Mickiewicza i kapitan Meyzner z Pogrzebu kapitana Meyznera Juliusza Słowackiego)," Prace Naukowe Wyższej Szkoty Pedagogicznej w Częstochowie 2003, part IX, p. 28.

38 S. Treugutt, "Książę niezłomny na ruinach Baru” [in:] Przemiany tradycji barskiej. Studia, ed. Z. Stefanowska, Kraków: Wydawnictwo Literackie, 1972, pp. 189-212.

39 "Respect the dream of the Holy child, / Who, when it opens its eyes [...] / Will cry first / As the dark from our tombs woken / Woven of our graves / Will frighten it / And the want of mother's womb / Will make it chirp in the crib.” J. Słowacki, Ksiadz Marek, op. cit., p. 19. Vide footnote 22. 
Douglas Brown, and clearly transparent in James Wait's rescue scene from the drowned cabin (cabin - grave - cradle - womb). ${ }^{40}$

Previously in his volume, Isolation and Ethos: A Study of Joseph Conrad's Works Wiesław Krajka notices the metaphor of "the cabin-funeral cave." The phantom of Wait's death infects everybody on board the "Narcissus," until the whole ship (resembling Soplicowo on water) becomes wedded to death and turns into a swimming grave:

The place for the crew is called a dark crypt, silent as a tomb. The bunks are called "narrow niches, fit for coffins in white and lit morgue" or graves inhabited by anxious ghosts." Captain Allistoun resembles a phantom appearing over a tomb; and officer Baker, an omnivorous beast prowling among corpses. Sleeping sailors are compared to dark mounds, evocative of neglected graves. $^{41}$

In that way, "darkness woven of our graves" envelops Bar and moves on board the "Narcissus" - one could say. Just as Bar is inhabited by graves, so do cabins of the "Narcissus" transform into niches made for grave.

$$
* * *
$$

Let's return to the parallel: Conrad - Mickiewicz. A lot of Conrad's revisory gestures in respect to Pan Tadeusz will remain unequivocal. It is hard to determine the significance of swine on board the "Narcissus." It is not true, as Józef Miłobędzki suggested in his classical essay: "Conrad in a Sailor's Jacket," that we know nothing of the cargo on the ship. ${ }^{42}$ The theme of pigs on the "Narcissus" intrigues us for a different reason than the plot and the motivation.

In the first chapter, which, perhaps, constitutes equivalence to the first book of Pan Tadeusz, there is a casual mention of swine on board the "Narcissus." Belfast, interested in pigs, becomes their guard and custodian, a swineherd ("Belfast, leaning thoughtfully on his elbow, above the bars, communed with them through the silence of his meditation" $\left.{ }^{33}\right)$. In The Nigger of the "Narcissus" there are even images in which Belfast listens to his comrades conversation, "scratching the ear of his favorite pig." ${ }^{44}$

After the introduction of the pigs' motif in the first chapter, which depicts the household - to use the language of Pan Tadeusz, the pigs disappear from The Nigger of the "Narcissus" altogether. We do not find any references to the lot of live cargo, either after the period of the storm or when the "Narcissus" arrives at port, as if Conrad prematurely abandoned an initiated motif or maybe amputated it deliberately.

\footnotetext{
${ }^{40}$ Vide footnote 18.

${ }^{41}$ W. Krajka, "Pozytywne postacie marynarzy. Etos walki, pracy i obowiązku" [in:] idem, Izolacja i etos. Studium o twórczości Josepha Conrada, Wrocław: Ossolineum, 1988, p. 182.

${ }^{42}$ J. Miłobędzki, "Conrad w żeglarskiej kurcie" [in:] Conrad w żeglarskiej kurcie. Wybór publicystyki morskiej, transl. (with introduction and commentary) J. Miłobędzki, Gdańsk: Wydawnictwo Morskie, 1972, p. 15.

${ }^{43}$ J. Conrad, The Nigger of the "Narcissus"..., op. cit., p. 19.

${ }^{44}$ Ibid., p. 20.
} 
In Pan Tadeusz, the equivalence to pigs is birds scrupulously and tenderly fed by Zosia "with pearl barley." 45 They become brutally butchered at the beginning of the foray by Sak, who is in love with Zosia.

It is worth adding that the birds in Soplicowo are a symbol of a specific metaphysical order and Zosia is its guardian; axis mundi of the epic, all the metaphysical values of the spiritual universe center in her. She is a goddess of golden weather-as Julian Przyboś wrote about her ${ }^{46}$ On this level, Conrad's pigs seem to be a travesty of Mickiewicz's world-garden. It's surprising that the travesty is incomplete and abandoned in the novella, as if the first chapter seemed a too widely stretched canvas for the author. The canvas, which cuts out the motifs that could identify the board of the "Narcissus" with Mickiewicz's Soplicowo.

In contrast to the exposed and also underexposed, transformed and as if incomplete intertexts from Pan Tadeusz (such as the motif of swine), the competitive intertexts could suggest Słowacki's influence, particularly of Father Marek and The Constant Prince, as they remain well anchored in the novella, even if their dimensions, character, and transformative force undergo a change, becoming either allusions or reminiscences and at other times tropes or "tonalities," perhaps less defined "emanations" of Słowacki's genesis style.

According to Albert J. Guérard, Conrad might have borrowed the anticipating elements, intuiting Wait's death - the elements enclosed within the ship microcosm - from Herman Melville's Benito Cereno ${ }^{47}$ One could argue with this statement, taking into account that the original, dynamic, and expanded image of nature anticipating the events is present in all opening parts of the twelve books of Pan Tadeusz. Moreover, what we perceived in Mickiewicz's text as the concert of nature, Joseph Conrad transposes onto the concert of the crew, using the narration techniques of impressionism. Conrad's "concert of humans," as virtuosic as Mickiewicz's concerts of nature, becomes - in the second chapter of the novel — the equivalence of the concerts of sunrises from the initial books of Pan Tadeusz:

Something like a weak rattle was heard through the forecastle door. It became a murmur; it ended in a sighing groan. The washerman plunged both his arms into the tub abruptly; the cook became more crestfallen than an exposed backslider; the boatswain moved his shoulders uneasily; the carpenter got up with a spring and walked away-while the sailmaker seemed mentally to give his story up, and began to puff at his pipe with sombre determination. In the blackness of the doorway a pair of eyes glimmered white, and big, and staring. Then James Wait's head protruding, became visible, as if suspended between the two hands that grasped a doorpost on each side of the face [my underlining K.S.]. ${ }^{48}$

Let's return to Guérard, and to Melville and Benito Cereno, because the scholar claims that, similarly to Benito Cereno, there are catastrophic anticipations of the plot development in The Nigger of the "Narcissus." Remembering, for now in general,

\footnotetext{
${ }^{45}$ J. Przyboś, op. cit., p. 102.

${ }^{46}$ A. Mickiewicz, Pan Tadeusz, op. cit., p. 236.

${ }^{47}$ A. Guérard, op. cit., p. 118.

${ }^{48}$ J. Conrad, The Nigger of the "Narcissus"..., op. cit., pp. 20-21.
} 
that we encounter nature with its concerts anticipating the catastrophe in books V-VIII of Pan Tadeusz, let's refer to Guérard:

"A heavy atmosphere of oppressive quietude pervaded the ship". Thus begins the fifth and last chapter. The threat of mutiny has been broken; we are nearing the end of the voyage; ultimate meanings must be achieved now or not at all; and James Wait must die. Like Melville in Benito Cereno Conrad has prepared us early in the story for the themes of ambiguity and death by mortuary images. ${ }^{49}$

Revoking the slightly possible influence of Benito Cereno on Conrad (and at the same time returning to Bloom's revisory methods, which I enumerated at the beginning of my essay), I would like to emphasize that as much as the first and second chapter of The Nigger of the "Narcissus" constitute kenosis in reference to the first book of Pan Tadeusz: The Estate [Gospodarstwo], the beginning of Conrad's fifth chapter is kenosis of initial parts (the description of horror and anguish in nature) of the opening of book 10 of Pan Tadeusz: Emigration. Jacek [Emigracja. Jacek, the book of Jacek Soplica's death]. The willows in Mickiewicz are compared to "mourners by a grave," and swallows "proud of their quick flight, / pierce the black clouds as though someone has pressed / a trigger and gunshots ripped through the night." The lull is portrayed in the following way: "The air grew still, but silence would not last, / for it was mute as though struck dumb from fear." ${ }^{50}$

What Guérard described as rooted in the Conrad novel's mortuary images, was included constitutively in the universe of Soplicowo and in the concerts of nature. The gothic and frenetic concert becomes the theme of the eighth book of the epic, The Foray $[$ Zajazd]:

Each night, with silent apprehension,

Lithuanians gazed at the sky,

tracking this celestial evil omen,

comparing it to others, asking why

they heard such sinister cries of birds

flocked in deserted fields, sharpening beaks,

as though expecting carrion rewards.

And why their dogs dug in the ground by creeks,

and howled furiously, as though the scent

of death their frantic tunneling unearthed -

for war or starvation these things portend.

And the forest watchman was not the first

to have seen, wandering through cemeteries,

the Maid of Pestilence, tall as the trees,

waving a bloody kerchief in the breeze..$^{51}$

${ }^{49}$ A.J. Guérard, "The Nigger of the 'Narcissus"” [in:] idem, Conrad the Novelist, Cambridge: Harvard UP, 1958, p. 118.

${ }^{50}$ A. Mickiewicz, Pan Tadeusz, op. cit., pp. 269-270.

${ }^{51}$ Ibid., p. 152. "Bo zbyt często słyszano krzyk złowieszczych ptaków, / Które na pustych polach gromadząc się w kupy, / Ostrzyły dzioby, jakby czekając na trupy; / Zbyt często postrzegano, że psy ziemię ryły / I jak gdyby śmierć wietrząc, przeraźliwie wyły: / Co wróży głód lub wojnę; a strażnicy boru / Widzieli, 
Not without a reason in Guérard's text, even the captain Allistoun "as a phantom above a grave has its place in a novel depending upon much mortuary imagery to prepare us for the occult death of Wait." 52 This way of seeing brings to mind the gothic style of Horace Walpole, but we should not limit ourselves to one source only. What about Mickiewicz's ballad Phantom [Upiór] with a well-known opening verse: "The Heart stopped, the chest is icy." 53 What about "thanatos-centric" Lithuanian stories and lore and what about the paradox of nature in Pan Tadeusz; nature understood as the concert of life and death?

To recapitulate, if well calibrated, the echoes of Polish Romanticism enrich The Nigger of the "Narcissus" with whole interpretative networks, creating an additional level to what already defined reception of Conrad's text. When considering Polish Romantic intertextuality, it is not sufficient to point only orientationally to some trajectories Conrad followed, as has been done for many years. One has to not only identify the romantic texts influencing Conrad (Mickiewicz's Pan Tadeusz, and Konrad Wallenrod, and Słowacki's The Constant Prince and Father Marek), but also clearly depict a hypothetical model of influence of the given titles on the author; the way in which Conrad could use these trajectories within his literary blueprint in his own way. For example, the technique of Mickiewicz's concerts of nature evolves into a higher, narratively impressionistic level of a "concert made of people"; the concert of the Narcissus's crew while immersed in work. This technique confirms, in this way, that the ship becomes "Soplicowo on water" of sorts.

What I attempted to illustrate is that, more often than not, Polish Romantic intertexts co-create spaces that have been until now filled entirely within the context of European literature (Maupassant and Bel-Ami-in Cedric Watt's opinion; Melville and Benito Cereno-according to Albert Guérard). The same intertexts can explain and contextualize intuitions that are atypical for scholars regarding The Nigger of the "Narcissus," for example, that of Douglas Brown in reference to James Wait's drowning cabin, perceived as "grave-womb-cradle", which acquires deeper meaning in the context of Słowacki's genesis plays.

Having said that, Polish Romantic intertext also plays in Conrad many independent functions. If accurately recognized, it illustrates constant reconfiguring of Conrad's primary material of images; each time creating a new constellation of uncertain, not always justifiable, references. These clear and detailed references to Conrad's "first romantic readings," although possible to dispute, in each manifestation creates a new constellation of intersecting networks of significant reminiscences; each time on a different basis, and collaborates with the already existing, visible network of contexts and intertexts in Conrad's prose.

This can fundamentally influence specific reception of the work and its interpretative revisions, just to give an example: certainly during the process of reading The Nigger of the "Narcissus," its metaphysical quality contributes to the reception of the

jak przez cmentarz szła dziewica moru, / Która wznosi się czołem nad najwyższe drzewa, / A w lewym ręku chustką skrwawioną powiewa.” A. Mickiewicz, Pan Tadeusz, ed. J. Krzyżanowski, op. cit., p. 215.

${ }^{52}$ A. Guérard, op. cit., p. 122.

${ }^{53}$ A. Mickiewicz, “Upiór” [in:] idem, Dzieła, ed. Z. J. Nowak, vol. III, Warszawa 1995, p. 9. 
text. The Nigger of the "Narcissus" is - in this respect - a novel under the auspices of a particularly understood metaphysical realism. Such reading is strengthened and magnified by unexpected reminiscences of Słowacki's genesis, and via Słowacki, also the reminiscences of Calderón and Calderonism, whose hidden presence in Conrad's fiction has been noted by Camille R. La Bossière. The Nigger of the "Narcissus" is neither isolated nor representative, or a prototypical case in this matter. It is, rather, symptomatic and not the one and only, and, as such - it is worth all the analysis and debates...

Transl. Ewa Chruściel

\section{BIBLIOGRAPHY}

Bibliografia literatury polskiej "Nowy Korbut”. Vol. 11: H. Gacowa. Juliusz Stowacki. Wrocław: Ossolineum, 2000.

Brown, Douglas. "Notes". In J. Conrad. The Nigger of the 'Narcissus'. Edited with a critical commentary by D. Brown. London: University of London Press Ltd., 1960.

Conrad, Joseph. "Do Kazimierza Waliszewskiego Pent Farm 5 grudnia 1903”. In idem. Listy. Ed. Z. Najder. Transl. H. Carroll-Najder. Warszawa: Państwowy Instytut Wydawniczy, 1968. . Murzyn z załogi "Narcyza”. Opowieść morska. Transl. B. Zieliński. Warszawa: Państwowy Instytut Wydawniczy, 1972.

The Nigger of the "Narcissus": An Authoritative Text, Backgrounds and Sources Reviews and Criticism. Ed. R. Kimbrough. New York: Norton, 1979.

Dąbrowska, Maria. "Fantazja Almayera, Murzyn z załogi "Narcyza"”. In Szkice o Conradzie. Edited with an introduction and footnotes E. Korzeniewska. Warszawa: Czytelnik, 1972.

Drobczuk-Zwolińska, Iwona. "Dwie śmierci romantyczne (Jacek Soplica z Pana Tadeusza Adama Mickiewicza i kapitan Meyzner z Pogrzebu kapitana Meyznera Juliusza Słowackiego)”. Prace Naukowe Wyższej Szkoty Pedagogicznej w Częstochowie IX (2003).

Gajewski, Krzysztof. "Lęk przed wptywem. Teoria poezji, Harold Bloom, trans. Agata BielikRobson, Marcin Szuster”. Pamiętnik Literacki 3 (2006).

Krajka, Wiesław. "Pozytywne postacie marynarzy. Etos walki, pracy i obowiązku". In idem. Izolacja i etos. Studium o twórczości Josepha Conrada. Wrocław: Ossolineum, 1988.

Krzyżanowski, Julian. "Wielkość i oryginalność Pana Tadeusza”. Pamiętnik Literacki 38 (1948).

Mickiewicz, Adam. Pan Tadeusz. In idem. Dzieła, vol. IV. Ed. J. Krzyżanowskiego. Warszawa 1955.

Pan Tadeusz or The Last Foray in Lithuania: a History of the Nobility in the Years 1811 and 1812. Transl. from Polish by L. Kress. HarrowGate Press 2006, http://leonardkress. com/Pan\%20Tadeusz.pdf [access: 19.07.2018].

Konrad Wallenrod. Powieść historyczna z dziejów litewskich i pruskich. In idem.

Powieści poetyckie. Vol. II. Ed. J. Krzyżanowski. Warszawa 1955.

Konrad Wallenrod. An Historical Poem. Transl. from the Polish into English Verse by Miss M. Ashurst Biggs. London: Trübner \& Co., 1982.

“Upiór" [Phantom]. In idem. Dzieła, vol. III. Ed. Z. J. Nowak. Warszawa 1995.

Miłobędzki, Józef. "Conrad w żeglarskiej kurcie”. In idem. Conrad w żeglarskiej kurcie. Wybór publicystyki morskiej. Transl. (with an introduction and commentary), J. Miłobędzki. Gdańsk: Wydawnictwo Morskie, 1972.

Peters, John G. "Development of Modern Conrad Commentary". In idem. Joseph Conrad's Critical Reception. Cambridge: Cambridge University Press, 2013. 
Przyboś, Julian. “Widzę i opisuję”. In idem. Czytając Mickiewicza. Warszawa: Oficyna Wydawnicza Rytm, 1998.

Retinger, Joseph H. Conrad and His Contemporaries: Souvenirs. New York: Roy Publishers, 1943. Słowacki, Juliusz. "Ksiądz Marek". In idem. Dzieła wybrane, vol. II. Edited with an introduction by M. Bizan and P. Hertz. Warszawa 2009.

. "Książę Niezłomny. (Z Caledrona de la Barca). Tragedia we trzech częściach". In idem. Dzieła wybrane, vol. II. Edited with an introduction by M. Bizan and P. Hertz. Warszawa 2009.

Stefanowska, Zofia. "Próba zdrowego rozumu". In eadem. Próba zdrowego rozumu. Studia o Mickiewiczu.Warszawa: Państwowy Instytut Wydawniczy, 1976.

Treugutt, Stefan. "Książę niezłomny na ruinach Baru”. In Przemiany tradycji barskiej. Studia. Ed. Z. Stefanowska. Kraków: Wydawnictwo Literackie, 1972.

Watts, Cedric. "Commentary". In J. Conrad. The Nigger of the 'Narcissus'. Edited, with an introduction and notes by C. Watts. London: Penguin Books, 1989. 